\title{
SUNNAH SEBAGAI SUMBER IPTEK DAN PERADABAN (Studi atas Pemikiran Yusuf Al-Qardhawi)
}

\author{
Risna Mosiba \\ Fakultas Ushuluddin, Filsafat dan Politik \\ Universitas Islam Negeri Alauddin Makassar \\ J1. H. M. Yasin Limpo No. 36, Samata, Gowa \\ risnasayang77@yahoo.com
}

\begin{abstract}
The topic of this paper is sunnah as a source of science and civilization. This topic is a new issue for Muslim intellectual treasures. Although the study has roots in turbans (inheritance) of Islamic knowledge, however the issue is so deep that it needs to be explored and disclosed in general. This issue is one of the topics that concerns the intellectuals of the IIIT institute (International Institute of Islamic Thought) in Washington. They then asked the intellectual of Islam to conduct the study. The discussion of Yusuf al-Qardhawi about sunnah as a source of science, technology and civilization, can be seen in his monumental masterpiece entitled al-Sunnah; Mashdaran lil Ma'rifat al-Hadharah. The thickness of this book reaches 311 pages and the content of the discussion consists of five main components. First, the introduction is an overview of the book's description. Second, tasrif Aspect (Yuridis) in the Sunnah. Third, sunnah as a Source of knowledge. Fourth, sunnah as a source of civilization. Fifth, the closing part.
\end{abstract}

Keywords: Sunnah, Science, Thoughts Yusuf Al-Qardhawi

\section{PENDAHULUAN}

1-Quran adalah sumber utama dan pertama dalam Islam, sedangkan hadis-
hadis Nabi adalah sumber kedua setelah al-Quran dalam Islam. Melihat hal ini,
hadis Nabi yang berasal dari tutur kata, prilaku maupun Nabi yang hidup pada beberapa abad lalu sudah bisa dipastikan terpengaruh dengan situasi dan kondisi masa lalu sehingga membutuhakan sebuah pemahaman baru terhadap hadis-hadis Nabi, ini tidak terlepas dari al-Quran sebagai sumber pertama dan utama yang juga menuntut pemahaman yang sesuai dengan situasi dan kondisi jaman sekarang.

Sejak lama umat Islam telah mengenal dan melekat pada pengetahuan yang mereka warisi secara turun temurun, bahwa sunnah merupakan sumber kedua setelah Alquran. Hal ini merupakan suatu aksioma yang tidak diper-selisihkan di kalangan umat Islam yang rela Allah sebagai Rabbnya, Islam sebagai agamanya dan Muhammad saw sebagai rasul Allah.

Al-Sunnah selain berfungsi sebagai sumber tasyri', ia juga merupakan sumber konsepsional dalam bidang Iptek dan Peradanban yang telah teruji dan terinplementasikan dalam tataran historis kultural pada masanya dengan laboratorium 
masyarakat Islam periode kenabian yang sempat menjadi mercusuar peradaban dunia yang diperhitungkan oleh masyarakat imperium tua dunia saat itu; Romawi dan Persia. ${ }^{1}$

Syaikh Yusuf al-Qardhawi merupakan tokoh dan ulama kontemporer yang amat piawai untuk menggagas keterkaitan antara al-Sunnah dengan Iptek dan Peradaban. Sebuah wacana baru dalam khazanah intelektual umat Islam yang selama ini masih terpendam.

Berkenaan dengan uraian singkat di atas, maka permasalahan yang akan menjadi fokus pembahasan makalah ini adalah:

1. Bagaimana biografi Yusuf al-Qardhawi?

2. Bagaimana metodologi Yusuf al-Qardhawi dalam membahas sunnah sebagai sumber Iptek dan Peradaban

3. Bagaimana gagasan Yusuf al-Qardhawi tentang sunnah sebagai sumber Iptek dan Peradaban?

4. Bagaimana pandangan Yusuf al-Qardhawi dalam memaknai hadis-hadis tentang Ekonomi?

\section{PEMBAHASAN}

\section{A. Biografi Yusuf Al-Qardhawi}

Yusuf al-Qardhawi, lahir di sebuah desa kecil bernama Saft Turab di Mesir tahun 1926. Sejak kecil ia hidup dalam kondisi yatim dalam asuhan pamannya. Kecerdasannya luar biasa, sejak usia 10 tahun mampu menghafal Alquran. Sehingga teman-teman sebayanya memanggil Syekh, gelar kehormatan yang diberikan pada seseorang yang memiliki keistimewaan dalam pengetahuan agama. Menamatkan pendidikan di Ma'had Thantha dan Ma'had Tsanawi, Qardhawi kemudian melanjutkan studynya ke Universitas Al Azhar, Fakultas Ushuluddin dan menyelesaikannya pada tahun 1952 M. Tapi gelar doktornya baru dia peroleh pada tahun 1972 dengan disertasi "Zakat dan Dampaknya dalam Penanggulangan Kemiskinan", yang kemudian di sempurnakan menjadi Fiqh Zakat. Sebuah buku yang sangat konprehensif membahas persoalan zakat dengan nuansa modern. Sebab keterlambatannya meraih gelar doktor, karena dia sempat meninggalkan Mesir akibat kejamnya rezim yang berkuasa saat itu. Kehidupannya di Mesir mulai mengalami pergeseran ketika terjadi penangkapan para aktivis Ikhwanul Muslimin oleh presiden Gemal Abdul Nasser. Sejak muda Yusuf alQaradhawi menjadi pengikut gerakan Ikhwanul Muslimin pimpinan Hasan al-Banna. ${ }^{2}$

Akibat peristiwa itu, Yusuf al-Qaradhawi meninggalkan Mesir menuju Qatar. Ia mendapat kewarganegaraan Qatar dan menjadikan Doha sebagai tempat tinggalnya.

1 Setiawan Budi Utomo, PengantarPenerjemah dalam Yusuf Qardhawi, As-Sunnah sebagai Sumber Iptek dan Peradaban; Diskursus Kontekstualisasi dan Aktualisasi Sunnah Nabi dalam Iptek dan Peradaban (Cet. I; Jakarta: Pustaka al-Kautsar, 1998), h. xi

2 Abdillah F. Hasan, Tokoh-tokoh Mashur Dunia Islam (Cet. I; Surabaya: Jawara, 2004), h. 321- 
Pada tahun 1977 mendirikan fakultas Syariah Universitas Qatar serta pusat kajian sejarah dan sunnah Nabi. Sebagai ulama yang berilmu tinggi, Yusuf al-Qaradhawi memahami arti pentingnya sebuah kemajuan yang menuntut pula pemahaman agama yang relevan dengan perkembangan itu. Banyak diketahui bahwa perkembangan peradaban telah banyak membawa pergeseran nilai-nilai religiusitas dalam paradigma yang keliru. Dalam berbagai gagasannya, Yusuf al-Qaradhawi termasuk tokoh yang memiliki kontribusi besar dalam membangun kembali citra Islam yang selaras dengan al-Quran maupun hadis. Hal ini tidak saja terdapat dalam berbagai ceramahceramahnya, tapi juga buku hasil karyanya yang banyak diminati umat.

Dalam perjalanan hidupnya, Qardhawi pernah pernah dipenjara sejak masa mudanya. Di Mesir, saat umurnya 23 tahun dipenjarakan oleh Raja Faruk pada tahun 1949, karena keterlibatannya dalam pergerakan Ikhwanul Muslimin. Pada April tahun 1956, ia ditangkap lagi saat terjadi Revolusi Juni di Mesir. Bulan Oktober, kembali ia mendekam di penjara militer selama dua tahun. Qardhawi terkenal dengan khutbahkhutbahnya yang berani sehingga sempat dilarang sebagai khatib di sebuah masjid di daerah Zamalek. Alasannya, khutbah khutbahnya dinilai menciptakan opini umum tentang ketidak adilan rezim saat itu. Qardhawi memiliki tujuh orang anak, empat putri dan tiga putra.

Yusuf Qardhawi dikenal sebagai ulama dan pemikir islam yang unik sekaligis istimewa, keunikan dan keistimewaanya itu tak lain dan tak bukan ia memiliki cara atau metodologi khas dalam menyampaikan risalah islam, lantaran metodologinya itulah dia mudah diterima di kalangan dunia barat sebagai seorang pemikir yang selalu menampilkan islam secara ramah, santun, dan moderat, kapasitasnya itulah yang membuat Qardhawi kerap kali menghadiri pertemuan internasional para pemuka agama di Eropa maupun di Amerika sebagai wakil dari kelompok islam. Dalam lentera pemikiran dan dakwah islam, kiprah Yusuf Qardhowi menempati posisi vital dalam pergerakan islam kontemporer, waktu yang dihabiskannya untuk berkhidmat kepada islam, bercearamah, menyampaikan masalah masalah aktual dan keislaman di berbagai tempat dan negara menjadikan pengaruh sosok sederhana yang pernah dipenjara oleh pemerintah mesir ini sangat besar di berbagai belahan dunia, khususnya dalam pergerakan islam kontemporer melalui karya karyanya yang mengilhami kebangkitan islam moderen. Sekitar 125 buku yang telah beliau tulis dalam berbagai demensi keislaman, sedikitnya ada 13 aspek kategori dalam karya karya Yusuf Al Qardhawi, seperti masalah masalah: fiqh dan ushul fiqh, ekonomi islam, ulum Al Quran dan As sunnah, akidah dan filsafat, fiqh prilaku, Dakwah dan Tarbiyah, gerakan dan kebangkitan islam, penyatuan pemikiran islam, pengetahuan islam umum, serial tokoh tokoh islam, sastra dan lainnya. Sebagian dari karyanya itu telah diterjemahkan ke berbagai bahasa termasuk bahasa Indonesia, tercatat, sedikitnya 55 judul buku Qardhawi yang telah diterjemahkan ke dalam bahasa Indonesia. Berikut sejumlah buku karya Qardhawi. 
Dalam bidang Fiqh dan Usul Fiqh. Sebagai seorang ahli fiqh, Qardhawi telah menulis sedikitnya 14 buah buku, baik Fiqh maupun Ushul Fiqh. Antara lain Al-Halal wa al Haram fi al-Islam (Halal dan Haram dalam Islam), Al-Ijtihad fi al-Shari'at alIslamiah (Ijtihad dalam syariat Islam), Fiqh al-Siyam (Hukum Tentang Puasa), Fiqh alTaharah (Hukum tentang Bersuci), Fiqh al-Ghina' wa al-Musiqa (Hukum Tentang Nyayian dan Musik ).

Dalam bidang ekonomi Islam, buku karya Qardhawi antara lain, Fiqh Zakat, Bay'u al-Murabahah li al-Amri bi al-Shira; (Sistem jual beli al-Murabah), Fawa'id alBunuk Hiya al-Riba al-Haram, (Manfaat Diharamkannya Bunga Bank), Dawr al-Qiyam wa al-Akhlaq fi al-Iqtisad al-Islami (Peranan nilai dan akhlak dalam ekonomi Islam), serta Dur al-Zakat fi alaj al-Musykilat al-Iqtisadiyyah (Peranan zakat dalam Mengatasi Masalah ekonomi).

Pengetahuan tentang al-Quran dan al-Sunnah. Qardhawi menulis sejumlah buku dan kajian mendalam terhadap metodologi mempelajari Alquran, cara berinterakhsi dan pemahaman terhadap Alquran maupun Sunnah. Buku-bukunya antara lain Al-Aql wa alIlm fi al-Quran (Akal dan Ilmu dalam al-Quran), Al-Sabru fi al-Quran (Sabar dalam alQuran), Tafsir Surah al-Ra'd dan Kayfa Nata'amal ma'a al-Sunnah al-Nabawiyyah (Bagaimana berinteraksi dengan sunnah).

Dalam bidang Akidah Islam, Qardhawi menulis sekitar emnpat buku, antara lain Wujud Allah (Adanya Allah), Haqiqat al-Tawhid (Hakikat Tauhid), Iman bi Qadr (Keimanan kepada Qadar).

\section{B. Metodologi Yusuf Al-Qardhawi Dalam Membahas Sunnah Sebagai Sumber Iptek Dan Peradaban}

Sejak masa lalu umat Islam telah mengakui bahwa sunnah Rasul saw. adalah sumber kedua syariat Islamiyah setelah Al-Quran. Hal itu tercatat dalam warisan ilmu pengetahuan mereka dan dijelaskan oleh ilmu ushul fikih dalam semua mazhab. Telah banyak kitab yang ditulis untuk menjelaskan hal itu, baik pada masa lampau maupun masa modern ini. In merupakan masalah yang tidak diperselisihkan oleh semua orang yang beragama Islam, dan mengakui bahwa Muhammad SAW adalah Rasulullah.

Sebagaimana dalam muqaddimah kitab, ada sebuah hal yang melatarbelakngi penyusunan kitab sebagaimana kitab-kitab hadis lainnya. Yakni sebuah kegelisan akademik, seperti perkataannya beliau berikut ini.

Dari segi judulnya dan isi pembahasanya, dapat dipahami bahwa buku tersebut menjadikan hadis Nabi saw sebagai obyek pembahasan, di mana Yusuf al-Qardhawi secara khusus menelaah hadis-hadis Nabi saw yang berkaitan dengan Iptek dan Peradaban. Berdasarkan hal ini, maka, dapat dirumuskan metode yang digunakan adalah tematik (mawdhu'iy). Terkait dengan tema bukunya itu, Yusuf al-Qardhawi menyatakan bahwa: 




Artinya:

Tema yang kita bicarakan dalam buku ini, yakni sunnah sumber ilmu pengetahuan dan peradaban-peradaban, adalah wacana baru dalam intelektual muslim. Walaupun masalah tersebut berakar dalam khasanah intelektual kita, namun sayangnya akar tersebut masih berada dalam benak kita, yang masih membutuhkan suatu upaya penggalian dan penguakan kembali, sehingga ia muncul secara jelas bagi para pengamat....

Dari pernyataan di atas, kelihatan bahwa Yusuf al-Qardhawi dengan metode tematik yang digunakannya ingin berusaha menampilkan sunnah (hadis) sebagai paradigma baru dalam memahami iptek dan peradaban. Dengan usaha yang dilakukannya ini, berdasar pada pemikirannya bahwa dalam sunnah sebenarnya telah tersimpang berbagai dogma tentang ilmu, namun sikap kepedulian sebagian umat Islam tentangnya belum terwujud. Sehingga menurutnya, bahwa dengan tema kajiannya ini akan berimplikasi pada sikap kepedualian (motivasi) dan atau respon balik dari para pengamat muslim kelak.

Di sisi lain, tidak heran bila seorang pengamat dan atau peneliti yang jeli menemukan banyak hal yang menarik dalam berbagai literatur sunnah. Suatu penemuan yang dapat memuaskan keinginannya serta membangkitkan semangatnya dalam mengkaji sunnah sebagai sumber Iptek dan peradaban.

Berdasarkan metode tematik itulah, Yusuf al-Qardhawi, membahas Iptek dan peradaban yang dirincinya ke dalam tiga topik utama sebagaimana yang termaktub dalam bukunya, sebagai berikut:

1. Tema mengenai aspek tasyri' (yuridis) pada sunnah

Pada bagian tema ini, meliputi pembahasan tentang sunnah sebagai tasyri' dan bukan tasyri': Sunnah sebagai tasyri umum dan khusus; dan sunnah sebagai ketetapan tasyri' yang abadi dan insidentil. Dalam hal ini, Shahib al-Kitāb berusaha untuk bersikap moderat antara kaum ekstrim dalam apresiasi sunnah dan antara kaum yang melecehkan sunnah.

2. Tema mengenai sunnah sebagai sumber Iptek

Pada bagian tema ini, pembahasannya meliputi ilmu pengetahuan agama yang berhubungan dengan hal-hal yang ghaib yang sumber satu-satunya adalah wahyu, yaitu persoalan yang terkait dengan rukun iman, serta peristiwa-peristiwa akhir

3 Yusuf al-Qadhawi, al-Sunnat; Mashdaran lil Ma'rifat wa al-Hadrahah (Cet. I; Kairo: Dar alSyuruq, 1997), h. 7 
zaman yang dalam pembahasannya disertai dengan fokus terhadap berita-berita sunnah yang menggembirakan tentang masa depan umat Islam, ataupun ilmu pengetahuan yang berkaitan dengan aspek-aspek kemanusiaan. Dalam pembahasan ini, Shahib al-Kitāb membatasi diri pada tiga aspek, yakni pendidikan, kesehatan, dan ekonomi. Demikian juga, ia membahas kaitan sunnah dengan sains.

3. Tema mengenai sunnah sebagai sumber Peradaban

Pada bagian tema ini, pembahasannya mencakup dua topik besar, yakni al-fiqh alhadhari dan al-suluk al-hadhari. Pembahasan atas keduanya, kelihatan sangat luas dan komprehensif. ${ }^{4}$

Dengan memperhatikan tema-tema pokok di atas, tampak bahwa metodologi yang digunakan Yusuf al-Qardhawi tetap bertumpuh pada sikap moderasi dan kajian langsung serta menyeluruh terhadap al-sunnah. Dalam aplikasi pembahasannya, ia tetap mempertimbangkan hubungan sunnah dengan Alquran, dan pemahaman para sahabat. Dengan demikian metode ma'tsur, merupakan bagian terpenting dalam pembahasannya. Hal ini dapat dilihat, misalnya ketika membahas hadis tentang perang (al-qitāl).

Sebelum mengurai masalah al-qitāl, Yusuf al-Qardhawi terlebih dahulu mengutip beberapa ayat, yakni QS. al-Nisa: 71 dan 102; serta QS. al-Anfāl: 60. Setelah itu, ia mengutip sebuah hadis tentang al-qitāl untuk diuraikannya.Teks Hadis yang dimaksud

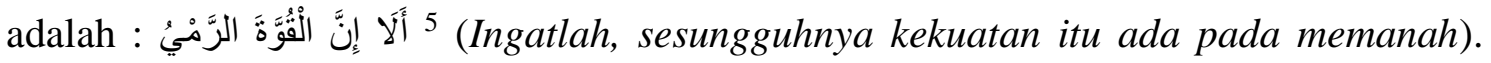
Setelah mengutip hadis ini, dan ia juga mengutip hadis-hadis yang senada, Yusuf alQardhawi lalu menerangkan tentang etika perang dengan mengacu pada firman Allah swt dalam QS. al-Baqarah: 190. Berkaitan dengan ini, Yusuf al-Qardhawi merumuskan bahwa boleh jadi dalam masa tertentu, pedang, tombak, dan panah merupakan persenjataan alternatif. Namun pada masa yang lain sejnata alternatif tersebut adalah manjaniq, dan masa yang lain lagi, senjata tersebut boleh diganti yang lebih canggih seperti meriam, bom, roket, peluru kendali dan selainnya. ${ }^{6}$ Jadi, dapat dipahami bahwa metode ma'tsur yang digunakan oleh Yusuf al-Qardhawi, adalah mengaitkan suatu hadis yang akan diuraikannya dengan mengutip beberapa ayat-ayat yang terkait.

Di samping penggunaan metode ma'tsur, Yusuf Qardhawi tidak dapat menghindarkan dirinya dari penggunaan ra'yu. Dalam hal ini, terlihat bahwa ketika ia menjelaskan masalah "peperangan" tersebut, dikaitkannya dengan masalah kemoderenan berdasarkan hasil analisisnya sendiri, misalnya; term al-ramyu tersebut disepadangkan dengan meriam, bom, roket, peluru kendali untuk masa kini. Dengan metode ra'yu ini, kelihatan bahwa Yusuf al-Qardhawi mengurai hadis-hadis, dengan cara mengetegahkan ide-ide cemerlang dalam bentuk kajian intelektual dengan analisis,

${ }^{4}$ Yusuf al-Qardahwi, op. cit., h. 8-9

${ }^{5}$ Ibid., h. 14-15. Lengkapnya hadis tersebut, lihat Abu al-Husain Muslim bin al-Hajjaj al-Qusyairi, Shahih Muslim dalam CD. Rom Hadis, Kitāb al-Imārah, hadis nomor ke-3541

${ }^{6}$ Uraian lebih lanjut, lihat Yusuf al-Qardhawi, ibid. 
linguistik, historis dan sosiologis. Metode terakhir inilah ( $\left.\mathrm{ra}^{\prime} \mathrm{yu}\right)$ dengan berbagai teknik analisis yang banyak digunakan oleh Yusuf al-Qardawi dalam mengurai (men-syarah) hadis-hadis. Teknik analisis yang dimaksud, adalah corak penafsiran (syarah) hadis berdasarkan ilmi, falsafi, adab ijtimai.

Teknik analisis dengan syarah ilmiy, terutama berkaitan dengan hadis-hadis yang menyangkut dengan ilmu pengetahuan dan teknologi, dan syarah ilmiy seperti yang paling dominan dalam karya Yusuf al-Qardhawi, karena memang pokus pembahasannya adalah tentang kaitan sunnah dengan Iptek. Syarah ilmiy tersebut secara jelas terlihat dalam pembahasan hadis-hadis tentang sunnah sebagai sumber ilmu pengetahuan, pada bagian kedua pembahasan dalam bukunya. Kemudian teknik analisis dengan syarah falsafi, adalah syarah hadis yang mengutamakan pemikiran filsafat, dan cara ini dominan ditemukan ketika Yusuf al-Qardhawi mebahas hadis-hadis tentang sunnah dan ilmu kesehatan. Yang terakhir adalah teknik analisis dengan corak al-adab al-ijtimai, yakni suatu corak syarahan hadis yang cenderung kepada persoalan sosial kemasyarakatan, dan mengutamakan keindahan gaya bahasa, dan model syarah seperti ini, dominan ditemukan dalam pembahasan Yusuf al-Qardhawi tentang fikih realitas, sunnah dan perilaku berbudaya.

Gabungan metodologis antara ma'tsur dan ra'yu dengan berbagai teknik analisis yang digunakan Yusuf al-Qardhawi tersebut, mengindikasikan bahwa al-Sunnah di samping sebagai sumber tasyri', juga sebagai sumber Iptek dan peradaban umat manusia pada masa kini, maupun masa mendatang. Sehingga budaya dan peradaban umat manusia akan terus dapat dipandu dalam bingkai al-Sunnah yang telah teruji dan berhasil itu.

\section{Gagasan Yusuf Al-Qardhawi tentang Sunnah Sebagai Sumber IPTEK dan Peradaban}

Dengan menyimak tiga tema pokok dalam karya Yusuf al-Qardhawi yang telah disebutkan, ditemukan beberapa gagasan penting beliau tentang eksistensi sunnah sebagai sumber Iptek dan Peradaban, sebagai berikut:

1. Universalisme Sunnah tentang Iptek dan Peradaban

Secara tegas Alquran menyatakan bahwa hadis adalah sumber tasyri' di samping Alquran. $^{7}$ Berkenaan dengan ini, Yusuf al-Qardhawi menyatakan bahwa sebagian golongan telah menyalahgunakan tafsiran hadis-hadis itu sendiri. Misalnya saja, hadis

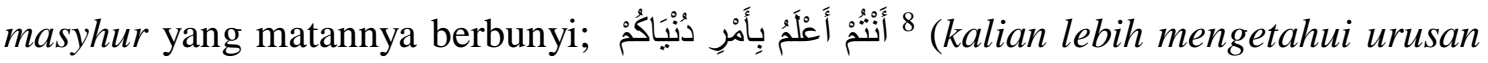
dunia kalian). Dengan memahami hadis ini, ada sebagian orang yang ingin menghapus

${ }^{7}$ Lihat misalnya, QS. al-Hasyr (59): 7; QS. Ali Imrān (): 32; QS. al-Nisa (4): 80, dan QS. al-Ahzāb (33): 21. Uraian lebih lanjut tentang kedudukan hadis, lihat M. Syuhudi Ismail, Kaidah Kesahahihan Sanad Hadis (Cet. I; Jakarta: Bulan Bintang, 1990), h. 20-22.

${ }^{8}$ Yusuf al-Qardhawi, op. cit., h. 12. Lihat lengkapnya dalam Shahih Muslim, op. cit., dalam Kitāb al-fadail, hadis nomor ke-4358. Lihat juga Abu Muhammad Ahmad bin Hanbal, Musnad Ahmad bin Hanbal dalam CD. Rom al-Hadis, Baqy al-Musnad al-Mukaśśirin hadis nomor ke-12086. 
sistim politik dalam Islam. Begitu, juga ada yang ingin menghapuskan seluruh sistem ekonomi dalam Islam. Mereka berusaha mengingkari sebagian syariah Islam dalam masalah muamalat, dan urusan sosial, karena dikategorikannya sebagai urusan dunia belaka. Berkenaan dengan hal tersebut, Yusuf al-Qardhawi lalu menegaskan bahwa hadis tersebut secara eksplisit maknanya tidak bertentangan dengan nash dan tidak menunjukkan tentang adanya pelarangan menggunakan sunnah sebagai dalil dalam setiap urusan. ${ }^{9}$ Artinya bahwa agama tidak campur dalam urusan-urusan manusia yang dimotivasi oleh naluri dan kebutuhan kehidupan duniawinya. Seperti halnya masalah "peperangan" yang telah dijelaskan, bahwa untuk masalah teknis dan teknik peperangan itu diserahkan kepada umat manusia dengan cara mengkondisikan dengan ilmu pengetahuan dan teknologi yang dimiliki oleh umat manusia, serta peradaban umat manusia itu sendiri yang semakin maju dan berkembang. Hal ini berarti bahwa universalisme hadis Nabi saw mencakup untuk segala situasi dan kondisi (shalih li kulli zaman wa makan).

Sebagian dari mereka ada yang berusaha mengingkari adanya sistem politik dalam Islam secara total dengan berdasarkan hanya satu hadis ini saja. Dikarenakan menurut mereka, masalah politik, baik pokok maupun parsialnya, adalah urusan duniawi kita, maka otomatis kita lebih tahu tentangnya. Wahyu tidak mempunyai kompetensi untuk memberikan aturan dan petunjuk dalam masalah ini. Bagi mereka, Islam adalah agama tanpa Negara dan akidah tanpa syariat.

Sebagian yang lain berusaha mengingkari adanya system ekonomi dalam Islam, juga dengan berdasarkan pada satu hadis ini.

Sebelum membahas lebih jauh tentang hadis tersebut guna menyanggah pendapat kedua kelompok ekstrem di atas, Al-Qardlawi mengutip pendapat para ahli Hadis yang mengomentari pendapat tersebut. Seperti pendapatnya muhaddis Syeikh Ahmad Syakir dalam Musnad Ahmad sebagai berikut: "Ia (Syekh Ahmad) berkata, "hadis ini telah didengung-dengungkan oleh orang-orang atheis mesir dan orang-orang yang terbaratkan, seperti para budak orientalis dan para murid missionaries, sebagai dalil untuk menyerang orang-orang bergelut dalam bidang syariat Islam. Mereka berusaha menghapus seluruh Sunnah dan mengingkari Syariat Islam dalam mengatur muamalah, tatanan social, dan sebagainya. Mereka berpendapat bahwa semua itu adalah urusan dunia dengan dasar hadis di atas.

Hal inilah yang di maksud Qardhawi bahwa ada sebagian hadis yang ditempatkan bukan pada tempatnya dan digunakan untuk tujuan yang buruk.

Menurut Qadhawi, ada dua varian kecenderungan yang kontradiktif dalam realita umat Islam saat ini.

Pertama, varian yang ingin menjadikan seluruh Sunnah yang diriwayatkan sebagai hokum yang harus diikuti oleh manusia diseluruh masa, tempat dan kondisi

${ }^{9}$ Yusuf al-Qardhawi, ibid., h. 13 
meskipun Sunnah itu ada yang timbul dari tindakan pribadi semata, dari adat istiadat, dari pengalaman atau yang persetujuan semata, tidak dengan tujuan tertentu.

Kedua, varian yang ingin memutuskan hubungan Sunnah dengan seluruh urusan dunia, menurut mereka, adat istiadat, muamalah, politik, admisnistrasi, perang, dan sebagainya harus diserahkan kepada manusia secara mutlak dan Sunnah tidak mempunyai kompetensi sedikitpun untuk mengaturnya. Dan dalil yang sering dipakai adalah Hadis diatas.

Lebih lanjut, Qardhawi menjelaskan makna hadis diatas yang moderat, yaitu sikap yang tidak mengikuti kedua varian diatas. Dan dalam memahaminya, Qardhawi melakukan pendekatannya dengan konsepnya sendiri. Salah satu konsep tersebut adalah kita harus bisa memilah sunnah yang berdimensi hukum yang harus diikuti dan dipraktikan manusia serta Sunnah yang tidak berdimensi hukum.

, menurutnya makna hadis sangatlah jelas, yaitu agama tidak turut campur dalam urusan-urusan manusia yang didorong oleh insting dan kebutuhan duniawinya, kecuali jika telah terjadi sikap berlebihan, berkurangan atau penyelewengan, agama akan turut campur tangan untuk mengaitkan seluruh gerak manusia dengan tujuan Rabbaniah.

Dalam masalah lain, misalnya bercocok tanam. Nabi saw dalam sebuah hadisnya, beliau bersabda:

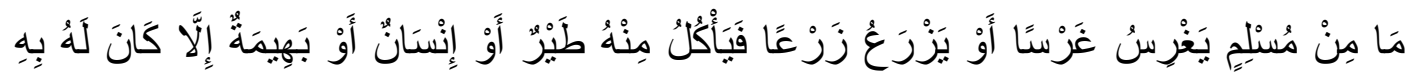

10 صنَدَفَّة 10

Artinya:

Tidaklah seorang muslim pun yang bertani atau bercocok tanam, lalu hasil tanaman itu di makan burung, orang, atau hewan, kecuali hal itu menjadi sedekah baginya.

Hadis ini, tidak mengajarkan kepada manusia bagaimana cara bercocok tanam, apa yang mesti ditanam, kapan menanam, dengan apa menanam, dan seterusnya. Karena demikian, halnya maka secara kontekstual hadis tersebut memberikan peluang luas bagi segenap manusia untuk bercocok tanam berdasarkan Iptek-nya, dan kekayaan peradaban yang dimiliki manusia itu sendiri, dan di sinilah keuniversalan makna hadis. Bahkan, dengan hadis ini maka pada gilirannya manusia dengan Iptek dan peradaban yang dimilikinya terinspirasi untuk berusaha menciptakan mesin bajak (traktor), mesin air untuk mengairi sawah, dan selainnya.

Dalam kesimpulannya, beliau mengatakan bahwa seluruh hadis-hadis tersebut dengan seluruh riwayatnya menunjukkan Rasul mengajukan sebuah praduga dalam salah satu masalah sumber penghasilan manusia. Hal ini tidak lepas dari bidang yang digeluti Beliau, Nabi tidak menggeluti bidang pertanian dan seni bercocok tanam. Jadi,

10 Ibid., h. 16. Lengkapnya hadis tersebut, lihat Abu Abdullah bin Mugihrah bin al-Bardizbat alBukhari, Shahih al-Bukhri dalam CD. Rom Hadis, Kitāb al-Muzārah, hadis nomor ke-2152. 
apa yang Beliau katakan adalah sebuah praduga dalam satu masalah nonagama dan semata masalah teknis, dan tentu saja mereka lebih mengerti dan lebih ahli dari pada Nabi yang terbilang seorang suadagar atau penggembala, oleh karena itu Nabi bersabda انتم اعلم بامر دنياكم

2. Sunnah identik dengan Wahyu sebagai pembimbing Akal dan Indra dalam memahami Iptek

Menurut Yusuf al-Qardhawi bahwa dengan akan dan panca indra yang dimiliki manusia, mereka dapat memahami dirinya dan alam sekitarnya. Dengan akal dan panca indra, manusia dapat mengkaji dan mengerti hukum alam dan rahasia yang tersimpan di dalamnya. ${ }^{11}$ Yang membimbing akal adalah wahyu Ilahi dan wahyu itu diturunkan kepada Nabi saw. Wahyu tersebut berupa risalah penutup yang terdapat dalam aqluran, wahyu terakhir yang menjadi petunjuk umat manusia, dan berupa sunnah Nabi yang menjelaskan dan menguraikan kandungan Alquran. ${ }^{12}$ Dari seperti ini, ke-lihatan bahwa gagasan Yusuf al-Qardhawi, adalah menempatkan Alquran dan sunnah sebagai sumber ajaran Islam yang utama, dan secara khusus, sunnah (hadis) merupakan instrumen penting dalam mendorong akal dan indra untuk memahami fenomena alam. Sunnah juga menurutnya, merupakan sumber pengetahuan, baik yang berkenaan dengan religius (keagamaan), humaniora (kemanusiaan), dan sosial yang dibutuhkan umat manusia untuk meluruskan jalan mereka, membetulkan kesalahan mereka ataupun melengkapi pengetahuan eksprimental mereka.

Sunnah dalam hal ini, sangat menyambut kehadiran akal dan indera manusia yang melahirkan ilmu pengathuan. Melalui arahan-arahan sunnah, justeru telah menciptakan iklim psikologis dan intelektual yang kondusif untuk terwujudnya kebangkitan ilmiah dalam dunia Islam.

3. Sunnah dan Urgensinya dalam Memahami Peradaban

Dalam Dalam khasanah intelektual sunnah sangat dengan peradaban, secara luas, dapat dijumpai beberapa petunjuk Nabi saw dalam sunnah yang mengarah pada persoalan fikih peradaban, perilaku beradab, dan bangunan peradaban. ${ }^{13}$

Fikih peradaban (al-fiqh al-hadhari) menurut Yusuf al-Qardhawi adalah fikih yang menghantarkan manusia dari pemahaman yang dangkal (primitif) menuju pemahaman yang luas dan mendalam mengenai alam dan kehidupan. ${ }^{14}$ Dengan rumusannya seperti ini, maka rambu pertama bagi fikih peradaban adalah ayat dan hukum alam.

\footnotetext{
${ }^{11}$ Uraian lebih lanjut Yusuf al-Qardhawi, ibid., h. 84.

${ }^{12}$ Ibid., h. 86.

${ }^{13}$ Ibid., h. 200.

${ }^{14}$ Ibid., h. 201.
} 
Tanda-tanda kekuasaan Allah yang tersebar di seluruh alam ini, tidaklah dapat dimanfaatkan dan dibaca kecuali oleh orang-orang yang berakal dan fikih (pemahaman yang arif). Allah telah menciptakan langit dan bumi, silih bergantinya siang dan malam, ${ }^{15}$ Allah juga menjadikan bintang-bintang, dan menciptakan manusia dari seorang diri. ${ }^{16}$ Untuk memahami fenomenan alam yang digambarkan ini, maka manusia dengan fikihnya adalah bersifat abadi, tetapi tetap dan selalu dapat diperbaharui, karena dari waktu ke waktu Allah selalu menguakkan rahasia alam kepada makhluknya. Yang perlu dipahami, adalah bahwa alam ini tidak berjalan tanpa aturan melainkan semuanya mengikuti takdir (ketentuan) Allah. Inilah yang disebut hukum alam (sunnatullah).

Namun demikian, menurut pengakuan Yusuf al-Qardhawi bahwa di antara sunnatullah tersebut, berimbas kepada merajalelanya degradasi moral, tersebarnya kemaksiatan dan kemungkaran, serta rusaknya kondisi umat dapat mendekatkan waktu kehancuran umat. Sungguh merupakan rahmat Allah yang tidak terhingga bahwa Dia tidak menghukum semua perbuatan manusia di dunia. ${ }^{17}$ Untuk menghindarkan kehancuran umat manusia dan agar kasih sayang atau rahmat Allah senantisa diberikanNya kepada umat manusia maka diperlukan perilaku yang beradab sebagaimana yang banyak dilansir dalam sunnah. Hal seperti secara tegas Alquran menyatakan bahwa Nabi saw adalah uswatun hasanah, atau dengan kata lain bahwa Nabi saw adalah yang paling beradab. Di sinilah pentingnya mengikuti sunnah dalam upaya meningkatkan peradaban manusia.

\section{Pemikiran Yusuf Al-Qardhawi tentang Hadis-hadis Ekonomi}

\section{Nilai dan Karakter Ekonomi Islam}

Kontekstualisasi Hadits-Hadits ekonomi dalam kitab as-Sunnah Mashdaran li alMa'rifah wa al-Hadlarah Pemikiran Yusuf al-Qaradâwi mempunyai pengaruh yang sangat signifikan di seluruh dunia. Pemikiran yang dinamik dan bersesuaian dengan keadaan dan suasana menjadikan dia sering menjadi rujukan. Di antara sumbangan besar Yusuf al- Qardhawi ialah memperkenalkan pendekatan dinamik untuk memahami Syariah. Pemikiran Yusuf Qardhawi tentang ekonomi lebih dititikberatkan pada perbedaan antara ekonomi Islam dengan ekonomi hasil teori manusia, yakni terletak pada nilai dan akhlak. Hal ini meliputi urgensi, kedudukan dan dampaknya dalam berbagai bidang ekonomi seperti produksi, konsumsi, perputaran dan peredaran.

Menurut Al-Qardhawi pemikiran-pemikiran ekonomi bukanlah pemikiran yang mapan dan permanen, akan tetapi mengalami perubahan dan pergantian (ditetapkan dan dihapuskan, menerima dan menolak sesuai berbagai aliran ekonomi yang ada), seperti yang akan dijelaskan di bawah ini:

Pertama; Ekonomi Islam. Ekonomi Islam, menurut Yusuf Qardhawi, berbeda

\footnotetext{
${ }^{15}$ Secara lengkap lihat QS. Ali Imran (3): 190

${ }^{16}$ Secara lengkap lihat QS. al-An'am (6): 97.-98

${ }^{17}$ Yusuf al-Qardhawi, op. cit., h. 203.
} 
dengan yang lain. Ekonomi Islam adalah "Ekonomi Ilahiah", "ekonomi berwawasan kemanusiaan", "ekonomi akhlak", dan "ekonomi pertengahan". Selanjutnya produksi, konsumsi, sirkulasi, dan distribusi merupakan cabang, buah dan dampak dari makna dan nilai keempat ekonomi di atas sebagai cerminan ataupun penegasan. Jika tidak, Yusuf Qardhawi menyebut ke-Islamannya hanya simbol belaka.

Kedua; Ekonomi Ilahiyah. Dikatakan Ekonomi Ilahiah karena bertitik berangkatnya dari Allah. Sehingga tujuan, cara dan kegiatan-kegiatan ekonomi diikatkan pada prinsip Ilahiah yakni tidak bertentangan dengan syari'at Allah SWT. Dasar ayat Al-qur'an berkaitan dengan hal ini tercantum dalam Qs. Al-Mulk: 15, Qs. Al-Baqarah: 168, Qs. Al-‘raf: 31-32, Qs. Al-Isra: 29, Qs. Saba: 15, Qs. Al-Baqarah: 72.

Dengan prinsip Ilahiah, seorang muslim akan selalu tunduk kepada aturan Allah dalam bermuamalah, sehingga ia akan menghindari sesuatu yang haram, tidak akan melakukan penimbunan, tidak akan berlaku zalim, menipu, menyuap dan menerima suapan, bahkan dari hal-hal syubhat. Ketika seorang muslim memiliki harta, hartanya tidak mutlak miliknya sehingga tidak bertindak sekehendak hatinya. Makna selanjutnya dari ekonomi Ilahiah, yakni menempatkan kegiatan ekonomi sebagai sarana penunjang baginya dan mejadi pelayanbagi aqidah dan risalahnya.

Ketiga; Ekonomi Islam. Yusuf Qardhawi juga menekankan bahwa ekonomi adalah bagian dari Islam, dan merupakan bagian yang dinamis serta penting, tetapi bukan asas dan dasar bagi bangunan Islam, bukan titik pangkal ajarannya, bukan tujuan risalahnya, bukan ciri peradaban dan bukan pula cita- cita umatnya. Ekonomi Islam yang Rabbani ini juga menjelaskan adaya pengawasan internal atau hati nurani, yang ditumbuhkan di dalam diri seorang muslim. Oleh sebab itu, Yusuf Qardhawi merasa pentingnya pendidikan iman dalam rangka mengarahkan perekonomian ke arah yang dikehendaki Islam dan mengendalikannya dengan hukum syariah. Dunia persaingan di alam liberalisasi ekonomi yang pelakunya ingin melahap segala sesuatu tetapi tidak pernah merasa kenyang dan tidak mengenal akhlak dan kemuliaan, iman menjadikan pemiliknya memiliki hati yang akan mencintai kebenaran, menginginkan kebajikan, dan mengharapkan kehidupan akhirat seelah dunia. Sehingga, mu'min yang memiliki harta, tidak akan pernah membiarkan harta itu memilikinya.

Keempat; Ekonomi Akhlak. Al-Qardhawi menyatakan bahwa antara ekonomi dan akhlak tidak akan pernah terpisah. Tidak hanya dalam ekonomi, akan tetapi berlaku juga dalam dunia politik, perang, dan ilmu. Dikatakan olehnya akhlak adalah daging dan urat nadi kehidupan Islami. Hal ini berdasarkan pada Risalah Islam adalah risalah akhlak, yakni dalam sabda rasulullah saw, "Sesungguhnya tiadalah aku diutus, melainkan hanya untuk menyempurnakan akhlak". Makna dari ekonomi akhlak ini adalah seorang muslim (baik pribadi ataupun bersama-sama) tidak bebas mengerjakan apa saja yang diinginkannya, ataupun apa yang menguntungkan saja. Hal ini dikarenakan seorang muslim terikat oleh iman dan akhlak pada setiap aktivitas ekonomi yang dilakukannya.

Kelima; Ekonomi Kemanusiaan. Dalam bahasan ekonomi kemanusiaan ini, Al- 
Qardhawi menjelaskan bahwa manusia adalah merupakan tujuan kegiatan ekonomi dalam pandangan Islam, sekaligus merupakan sarana dan pelakunya, yakni dengan memanfaatkan ilmu yang diberikan Allah kepadanya. Lebih lanjut beliau menuliskan nilai kemanusiaan terhimpun dalam ekonomi Islam pada sejumlah nilai yang dengannya lahir warisan yang berharga dan peradaban yang istimewa. Nilai ini yang terkandung dalam makna dari zakat yang diperintahkan Allah. Di samping itu, ekonomi manusia yang dimaksud oleh Al- Qardhawi, adalah mewujudkan kehidupan yang baik bagi manusia. Dijelaskan dalam pandangan Islam kehidupan yang baik terdiri dari dua unsur yang saling melengkapi yakni Unsur Materi dan Unsur Ruhani. Zuhud (kesederhanaan) yang diajarkan Islam adalah kemampuan mengatasi syahwat kehidupan dan gemerlapnya dunia dan mendahulukan akhirat daripada dunia, jika keduanya bertentangan. Sehingga disimpulkan, harta yang menjadikan orang muslim bahagia adalah harta yang mencukupinya, dan menjaganya dari meminta-minta kepada orang lain.

Keenam; Ekonomi Pertengahan. Ekonomi pertengahan bermakna keadilan yang ditegakkan oleh Islam diantara individu dengan masyarakat. Sistem ekonomi Islam tidak seperti kapitalis, juga tidak seperti sosialis. QS. Ar-Rahman: 7-9, "Dan Allah telah meninggikan langit dan Dia meletakkan neraca (keadilan), supaya kamu jangan melampaui batas tentang neraca itu, dan tegakkanlah timbangan itu dengan adil dan janganlah kamu mengurangi neraca itu."

Nilai pertengahan dan keseimbangan yang dibawa oleh Islam adalah berkaitan dengan dua aspek, yakni harta dan pemilikan. Harta hanya merupakan sarana untuk mencapai kebaikan berupa hubungan baik dengan Allah dan kepada sesama makhluk. Al-Qardhawi juga membantah pendapat orang yang mengaku ahli tasawwuf bahwa memperbanyak harta merupakan penghalang kepada Allah dan siksaan, sedangkan menyimpannya merupakan hal yang bertentangan dengan tawakal. Hal ini dikaji dari tujuan dan dampaknya.

\section{Nilai Dan Moral Dalam Kegiatan Ekonomi}

\section{Produksi}

Yusuf Al-Qardhawi mengawali penjabaran mengenai kegiatan produksi bukanlah menjadi pusat perhatian ekonomi Islam, akan tetapi pada pendistribusian harta. Lebih lanjut ia menggali arti produksi menurut para ahli ekonomi adalah kekayaan alam yang Allah ciptakan untuk kemudian dikelola dengan menggunakan akal yang disertai ilmu dan amal. Kekayaan alam itu berupa fauna, flora, pertambangan, matahari dan bulan. Penekanan kembali titik produksi adalah kewajiban dalam amal bagi yang mampu, dijabarkan seorang muslim tidak boleh duduk berpangku tangan, tidak mau berusaha dengan alasan sibuk ibadah dan tawakal kepada Allah.

Al-Qardhawi membagi unsur pokok dalam produksi hanya dua saja, yakni tanah (alam) dan kerja. Alam (bumi) adalah tanah lapangan dan medannnya, sedangkan manusia adalah pekerjanya, untuk modal sendiri beliau menggolongkannya sebagai alat 
dan prasarana yang merupakan hasil dari kerja. Kerja disini dipandang sebagai ibadah, dan menuntut setiap muslim untuk mandiri memenuhi kebutuhannya (sendiri, keluarga, masyarakat, bahkan untuk kehidupan dan makhluk secara umum).

Kegiatan produksi ini menuntut profesional seseorang dalam beramal. Hal ini berkaitan dengan dua akhlak pokok, yakni amanah dan Ikhlas. Makna amanah dan ikhlas ini menyebabkan ia merasa pekerjaanya diawasi Tuhannya. Al-Qardhawi juga mengaitkan produktifitas dengan ketenangan jiwa dan pengaruh istiqomah serta nilai waktu dalam diri.

Pembatasan seorang muslim terhadap yang halal dalam kegiatan produksi juga menjadi kajian yang tak terpisahkan. Ini merupakan salah satu letak perbedaan dari sistem ekonomi buatan manusia. Yang tidak mengenal batas-batas halal dan haram. Dan pemeliharaan sumber daya alam merupakan tugas manusia yang diamanahkan Allah untuk menjadi khalifah.

Tujuan Produksi mencakup dua pokok yakni merealisasikan pemenuhan kebutuhan baginya dan merealisasikan kemandirian umat. Islam tidak rela umatnya hidup pada tingkatan yang kehidupan yang rendah dan kekurangan. Adapun tingkat kelayakan yang sedapat mungkin dicapai adalah: jumlah makanan dan air yang cukup (agar ia kuat untuk melaksanakan ibadah dan menjaga kebersihan dirinya), pakaian yang menutup aurat, dan tempat tinggal yang sehat. Sedangkan kemandirian umat mengandung makna terpenuhinya kebutuhan pengembangan peradaban dan ketentraman, jalan yang disebut "fardhu kifayah" (mencakup ilmu, amal, industri).

\section{Konsumsi}

Mencapai kemandirian bagi setiap individu dan umat agar produktif hingga akhirnya merealisasikan kecukupan mendapat penekanan dalam hal ini, Al-Qardhawi menjadikan hadis sebagai dasar pentingnya mandiri dan larangan untuk bergantung kepada orang lain atau menerima shadaqah dari mereka padahal ia kuat dan mampu bekerja dengan ancaman bara api.

Kaum Muslim boleh meminta dalam beberapa hal, sesuai hadis kisah Qabisah bin Mukhariq berikut: Berkata Qabisah, "Aku memikul sebuah beban, lalu aku datang kepada Rasulullah Saw meminta sebagiannya. Rasulullah saw bersabda: "Berdirilah sampai ada orang yang datang untuk bershadaqah (zakat). Aku akan menyuruhnya agar shadaqah itu diberikan kepadamu." Kemudian Rasulullah saw bersabda, "Wahai Qabisah sesungguhnya meminta-minta itu tidak halal kecuali bagi salah satu dari tiga orang: seseorang memiliki beban berat, maka halal baginya meminta-minta, sehingga ia dapat memenuhinya sendiri. Seseorang yang tertimpa musibah yang menghabiskan hartanya, maka boleh baginya untuk meminta sehingga orang itu dapat memenuhi kebutuhan hidupnya sendiri. Seseorang yang tertimpa suatu kesulitan maka halal baginya meminta, sehingga mampu memenuhi kebutuhannya sendiri. Orang tersebut harus diperkuat tiga saksi dari kaummnya yang menyatakan bahwa orang itu hidupnya susah. Selain yang tiga ini jika meminta, wahai Qabisah, adalah haram, pelakunya sama 
dengan memakan barang haram" (HR. Muslim, Abu Daud, dan Nasa'i).

Merealisasikan pemenuhan kebutuhan umat, dilakukan melalui berbagai cara dan prasarana secara konseptual dan operasional dilakukan bersama-sama (terutama para penguasa yang diberi amanah). Cara tersebut meliputi, kebutuhan perencanaan, persiapan sumber daya manusia dan pembagian tugas yang baik, memberlakukan sumber daya alam dengan baik, keragaman produksi, mengoptimalkan fungsi kekayaan Konsumsi Konsumsi mendorong masyarakat untuk memproduksi, hal ini agar terpenuhinya kebutuhan.

Dalam nilai dan moral pada bidang ini adalah bagaimana konsumsi diarahkan kepada hal-hal yang baik dan memerangi kebakhilan serta kekikiran. Kewajiban berinfaq dengan dua orientasi infaq yang dituntut adalah infaq dijalan Allah dan nafkah kepada diri dan keluarga. Setelah seseorang muslim tidak bebas untuk mendapatkan harta dengan jalan haram, ia juga dibatasi dalam pengeluarannya kepada yang haram.

Hal ini sebagai penjagaan diri terhadap pertanggung jawaban terhadap harta tersebut. Seorang muslim juga diharuskan menyeimbangkan antara pemasukan dan pengeluaran agar sebisa mungkin terhindar dari berhutang. Selain itu, nilai dan moral dalam bidang konsumsi mengajarkan untuk menjaga barang- barang inventaris. Selain itu, Islam tidak menganjurkan hidup dalam kemewahan.

Dijelaskan bahwa sesungguhnya kemewahan adalah perusak individu karena kemewahan menyibukkan manusia dengan nafsu perut dan kemaluannya, melalaikan dari hal-hal mulia dan akhlak luhur, disamping membunuh semangat jihad, kesungguhan dan keperihatinan, dan menjadikannya hamba kehidupan santai dan kesenangan. Demikian pula larangan Islam berupa kecaman Al-qur'an bagi sikap pemborasan dan menyia-nyiakan harta. Sehingga Islam membatasi tentang pembelanjaan harta ada dua kriteria, yakni batasan yang terkait dengan kriteria sesuatu yang dibelanjakan berupa cara dan sifatnya, serta batasan yang terkait dengan kuantitas dan ukurannya.

Penjelasannya adalah, setiap pembelanjaan dalam hal-hal yang diharamkan adalah sesuatu perbuatan boros yang dilarang Islam. Maksud selanjutnya adalah membelanjakan barang atau konsumtif berlebihan terhadap barang yang tidak diperlukan. Pembatasan konsumsi yang ditunjukkan Islam kepada beberapa sasaran pendidikan moral, pendidikan sosial, pendidikan ekonomi, pendidikan kesehatan dan jasmani, pendidikan kemiliteran dan politik. Perputaran/Sirkulasi. Yang dimaksud sirkulasi/perputaran adalah sejumlah transaksi dan operasi yang dipakai orang untuk sirkulasi barang dan jasa.

Perbedaan ekonomi Islam dalam hal ini dikatakan oleh Al-Qardhawi, berjalan menurut aturan yang berbeda dari sistem komunis yang meniadakan kebebasan pasar, dan berbeda dari sistem kapitalis yang membiarkan pasar menjadi liberal sehingga memangsa orang-orang lemah. Dalam proses perputaran ini diharamkan memperdagangkan barang-barang haram, kemudian proses ini dalam Islam 
menanamkan kejujuran, amanat, dan nasihat (nasihat disini adalah menyukai kebaikan dan manfaat bagi orang lain sebagaimana untuk dirinya sendiri). Selain itu pula nilainilai yang ditetapkan adalah sikap adil dan pengharaman riba. Selanjutnya, yaitu kasih sayang dan pengharaman monopoli, disini menekankan nilai toleransi, ukhuwah dan shadaqah, dan pada titik akhirnya nilai ini bermuara pada bekal pedagang menuju akhirat.

\section{Distribusi}

Dalam ekonomi kapitalis, distribusi memiliki empat komponen yang berandil, yakni upah, bunga, ongkos, keuntungan, Islam menolak komponen bunga. Hal ini telah disepakati para ulama Islam dan lembaga fiqh kontemporer juga telah mengadakan konsesus bahwa setiap bentuk bunga adalah riba.

Pemikiran Yusuf Qardhawi tentang hadits-hadits ekonomi dalam kitab as-Sunnah Mashdaran li al-Ma'rifah wa al-Hadlarah secara jelas mengemukakan konsep-konsep ekonomi Islam yang lebih berorientasi bagaimana kesejahteraan ekonomi, dan keadilan sosial dapat dicapai dan dirasakan secara bersama, bukan pengumpulan harta sebanyakbanyaknya, dan keuntungan sebesar-besarnya sebagaimana yang dianut oleh prinsip ekonomi konvensional. Dalam bidang produksi, seorang hendaknya bekerja pada bidang yang dihalalkan, tidak melampaui hal yang diharamkan oleh Allah, juga memelihara sumber daya alam agar tetap terjaga keberlangsungannya. Dalam bidang konsumsi, seorang muslim harus membelanjakan harta pada hal-hal yang baik, tidak bakhil serta tidak kikir. Seorang muslim juga hendaknya hidup sederhana dan menghindari kemubaziran.

Dalam mendistribusikan hasil produksi hendaknya seorang muslim melandaskan kegiatannya pada nilai kebebasan yang dibingkai dalam nilai keadilan. Mewujudkan bisnis yang beretika berarti menjalankan suatu usaha atau pekerjaan yang dapat menghasilkan keuntungan sesuai dengan hukum yang telah ditetapkan oleh agama Islam. Upaya tersebut dapat dilakukan dengan cara; pertama, melakukan suatu rekonstruksi kesadaran baru tentang bisnis. Kedua, diperlukan suatu cara pandang baru dalam melakukan kajian- kajian keilmuan tentang bisnis dan ekonomi yang lebih berpijak pada paradigma pendekatan normatif sekaligus empirik induktif yang mengedepankan penggalian dan pengembangan nilai-nilai, agardapat mengatasi perubahan dan pergeseran zaman yang semakin cepat.

Islam telah memberikan peringatan dan hanya membolehkan usaha yang dilakukan dengan adil, jujur dan cara yang bijaksana. Dalam mencapai sasaran ini, Islam tidak memberikan kebebasan tanpa batas dalam usaha ekonomi. Selain itu, Islam tidak juga terlalu mengikat manusia dengan pengawasan ekonomi. Islam telah memberikan prinsip-prinsip produksi yang adil dan wajar dalam bisnis, dimana setiap orang dapat memperoleh kekayaan tanpa mengeksploitasi individu lain atau merusak kemaslahatan masyarakat. 
Seseorang dalam bekerja dalam pandangan Islam haruslah ihsan(baik) dan jihad (bersungguh-sungguh). Karena Islam bukan semata-mata memerintahkan bekerja, namun bekerja dengan baik. Karena sungguh-sungguhan dalam bekerja atau lazimnya disebut professional merupakan salah satu implementasi dari iman. Dengan bekerja profesional, maka seseorang akan mendapatkan ketenangan jiwa, ketenangan jiwa akan berpengaruh positif terhadap produktifitas. Dengan demikian, dapat dimaknai bahwa aktifitas yang demikian akan membebaskan usaha atau bisnis dari kezaliman dan penindasan. Senada dengan rambu-rambu Islam yang memberikan keadilan dan persamaan prinsip produksi sesuai kemampuan masing-masing tanpa menindas orang lain atau menghancurkan masyarakat.

\section{PENUTUP}

Berdasar pada permasalahan yang telah ditetapkan dan kaitannya dengan uraian terdahulu, maka dapat dirumuskan kesimpulan bahwa, Yusuf al-Qardhawi adalah tokoh muslim (ulama) yang telah banyak memberikan sumbangan pemikiran di era kontemporer. Pemikiran beliau dapat dicermati dalam sebuah karyanya yang berjudul al-Sunnah; Mashsaran lil Ma'rifah wa al-Hadharah.

Karya Yusuf al-Qarhawi tersebut, secara khusus membahas tentang kontektualisasi dan aktualiasasi al-sunnah dalam Iptek dan Peradaban. Pembahasan Yusuf al-Qardhawi dalam karyanya tersebut, menggunakan metode tematik. Hadishadis yang dibahasnya, mengacu pada gabungan metodologis antara ma'tsur dan ra' yu dengan teknik analisis linguistik, historis dan sosiologis, dengan corak ilmi, falsafi, dan adab ijtimai.

Penulisan menemukan tiga gagasan penting Yusuf al-Qardhawi dalam kaitannya eksistensi sunnah sebagai sumber Iptek dan Peradaban. Pertama, cakupan universalisme sunnah terhadap Iptek dan Peradaban. Kedua, sunnah identik dengan Wahyu sebagai pembimbing Akal dan Indra dalam memahami Iptek. Ketiga, Sunnah dalam kedudukannya sangat urgensi dalam memahami peradaban. Dengan gagasan Yusuf alQardhawi ini, maka harus dipahami bahwa eksistesni sunnah sesungguhnya, adalah telah mengangkat taraf hidup, dan memajukan kehidupan individu manusia dan masyarakat.

Pemikiran Yusuf Qardhawi tentang hadits-hadits ekonomi dalam kitab as-Sunnah Mashdaran li al-Ma'rifah wa al-Hadlarah secara jelas mengemukakan konsep-konsep ekonomi Islam yang lebih berorientasi bagaimana kesejahteraan ekonomi, dan keadilan sosial dapat dicapai dan dirasakan secara bersama, bukan pengumpulan harta sebanyakbanyaknya, dan keuntungan sebesar-besarnya sebagaimana yang dianut oleh prinsip ekonomi konvensional.

Berdasarkan rumusan kesimpulan di atas, maka kajian ini berimplikasi tentang pentingnya wacana baru untuk lebih memahami sosok Yusuf al-Qardhawi, dan pemikirannya tentang al-Sunnah sebagai sumber sumber Iptek dan Peradaban. 


\section{DAFTAR PUSTAKA}

Al-Qur'an al-Karim

Al-Bukhari. Abu Abdullah bin Mugihrah bin al-Bardizbat. Shahih al-Bukhari dalam CD. Rom Hadis, Kitāb al-Muzārah.

Hasan, Abdillah F. Tokoh-tokoh Mashur Dunia Islam. Cet. I; Surabaya: Jawara, 2004.

Ibn Hanbal, Abu Muhammad Ahmad. Musnad Ahmad bin Hanbal dalam CD. Rom alHadis, Baqy al-Musnad al-Mukaśśirin.

Ismail, M. Syuhudi. Kaidah Kesahahihan Sanad Hadis. Cet. I; Jakarta: Bulan Bintang, 1990

Nur Wahid, M. Hidayat. "Kata Pengantar" dalam Yusuf Qardhawi, As-Sunnah sebagai Sumber Iptek dan Peradaban; Diskursus Kontekstualisasi dan Aktualisasi Sunnah Nabi dalam Iptek dan Peradaban. Cet. I; Jakarta: Pustaka al-Kautsar, 1998.

Al-Qadhawi, Yusuf. al-Sunnat; Mashdaran lil Ma'rifat wa al-Hadrahah. Cet. I; Kairo: Dar al-Syuruq, 1997

Al-Qusyairi, Abu al-Husain Muslim bin al-Hajjaj. Shahih Muslim dalam CD. Rom Hadis, Kitāb al-Imārah.

Utomo, Setiawan Budi "Pengantar Penerjemah" dalam Yusuf Qardhawi, As-Sunnah sebagai Sumber Iptek dan Peradaban; Diskursus Kontekstualisasi dan Aktualisasi Sunnah Nabi dalam Iptek dan Peradaban. Cet. I; Jakarta: Pustaka al-Kautsar, 1998. 